\title{
PENGARUH ISOLAT PROTEIN KEDELAI TERHADAP KARAKTERISTIK FISIK DAN KIMIA KEFIR BUBUK
}

\section{Effect of Soy Protein Isolate on Physical and Chemical Characteristics of Kefir Powder}

\author{
Heni Rizqiati1 ${ }^{1 *}$, Nurwantoro ${ }^{1}$, Andi Febrisiantosa ${ }^{2}$, Claradhita Ayu Shauma ${ }^{1}$, Rani Khasanah $^{1}$ \\ 1) Jurusan Teknologi Pangan, FPP Universitas Diponegoro, Semarang \\ Kampus drh. R. Soejono Koesoemowardojo Tembalang Semarang 50275 \\ 2) Balai Penelitian Teknologi Bahan Alam - Lembaga Penelitian Indonesia \\ *Penulis Korespondensi, Email: henirizqi92@gmail.com
}

\begin{abstract}
ABSTRAK
Pembuatan kefir bubuk melalui pengeringan merupakan pengolahan lanjutan yang dapat menghindari pertumbuhan bakteri yang tidak diinginkan, memperpanjang masa simpan, mempermudah distribusi, dan memperkecil ruang penyimpanan kefir. Isolat Protein Kedelai (IPK) merupakan bahan pengisi yang umum digunakan pada pengolahan pangan dan memiliki sifat sebagai emulsifier sehingga diharapkan dapat mempercepat kelarutan produk. Tujuan penelitian ini untuk mengetahui pengaruh IPK terhadap rendemen, total padatan terlarut, nilai $\mathrm{pH}$, derajat kecerahan, kelarutan, kadar air, aktivitas air $\left(\mathrm{a}_{\mathrm{w}}\right)$, dan total asam kefir bubuk. Penelitian menggunakan metode Rancangan Acak Lengkap dengan variasi perlakuan yang diberikan yaitu T0 (tanpa penambahan IPK), T1 (penambahan IPK 2.5\%), T2 (penambahan IPK 5\%), T3 (penambahan IPK 7.5\%), dan T4 (penambahan IPK $10 \%)$. Diperoleh hasil bahwa penambahan IPK menunjukkan adanya pengaruh nyata $(p<0.05)$ terhadap peningkatan rendemen dan nilai $\mathrm{pH}$, serta penurunan total padatan terlarut, derajat kecerahan, kadar air, kelarutan, dan total asam. Kefir bubuk dengan penambahan IPK 2.5\% merupakan perlakuan terbaik.
\end{abstract}

Kata kunci: Bahan pengisi, Fisik, Isolat protein kedelai, Kimia, Kefir bubuk

\section{ABSTRACT}

Making kefir powder through drying is an advanced processing that can extend the shelf life and reduce the storage space. Soy Protein Isolate (SPI) is a filler material commonly used in food processing and has properties as an emulsifier so that it is expected to accelerate the solubility of the product. The purpose of this research is to find out the effect of adding SPI to physical and chemical characteristic kefir powder. This research includes making kefir powder by adding SPI, testing parameters, and analyzing the data. This study used a Completely Randomized Design method with the addition of various concentrations SPI. The results obtained that the addition of SPI had a significant effect $(p<0.05)$ on the increase in yield and $\mathrm{pH}$ values, and decrease in total dissolved solids, degree of brightness, water content, solubility, and total acid. Kefir powder with the addition of $2.5 \% \mathrm{SPI}$ is the best treatment.

Keywords: Chemical, Filler, Kefir powder, Physical, Soy protein isolate

\section{PENDAHULUAN}

Kefir adalah salah satu minuman fermentasi yang dibuat dengan menambahkan kefir grain ke dalam susu kemudian difermentasi sehingga menghasilkan rasa, warna, dan konsistensi seperti yoghurt serta beraroma alkohol (Rossi et al., 2016). Menurut Sawitri (2011), dalam proses pengolahannya, susu segar difermentasi menggunakan kefir grain. 
Kefir grain mengandung Bakteri Asam Laktat (BAL) seperti Lactobacillus lactis, Lactobacillus kefirgranum dan Lactobacillus kefiranofaciens serta beberapa jenis khamir seperti Leuconostoc dan Candida kefir. Masa simpan kefir yaitu 14 hari jika dilakukan penyimpanan pada suhu $4^{\circ} \mathrm{C}$ (Harald, 2002). Untuk memperpanjang masa simpan dan mempermudah distribusi maka, dapat dilakukan pengolahan lebih lanjut yakni menjadi kefir bubuk. Pembuatan kefir bubuk melalui pengeringan merupakan pengolahan lanjutan yang bertujuan untuk mencegah kontaminasi bakteri yang tidak diinginkan, memperpanjang masa simpan, dan memperkecil ruang penyimpanan kefir.

Prinsip pembuatan produk bubuk adalah dengan menghilangkan kandungan air pada bahan pangan hingga batas tertentu sehingga dapat menghambat aktivitas kimia dan mikroorganisme (Imanningsih, 2013). Metode pengeringan yang dapat digunakan adalah cabinet dryer. Pengeringan dengan cabinet dryer memiliki beberapa keunggulan yaitu bahan menjadi lebih awet, pengeringan lebih cepat dan lebih ekonomis (Mardiah et al., 2012).

Proses pengeringan kefir perlu ditambahkan bahan pengisi (filler). Bahan pengisi merupakan suatu bahan yang dapat mengurangi kerusakan akibat panas, mempercepat pengeringan, melapisi komponen dalam bahan termasuk flavor serta meningkatkan rendemen dan total padatan (Haryanto, 2016). Bahan pengisi yang umum ditambahkan pada produk pangan ada beragam jenisnya, salah satunya adalah Isolat Protein Kedelai (IPK). IPK merupakan produk olahan dari kedelai dengan kandungan protein paling sedikit $90 \%$ dalam berat kering dan banyak diaplikasikan pada produk pangan (Suseno et al., 2016). IPK mengandung protein amfifatik dengan asam amino gugus hidrofilik di luar yang dapat berikatan dengan air dan gugus hidrofobik di dalam yang tidak dapat berikatan dengan air (Pangastuti et al., 2013). Selain itu, IPK memiliki sifat foaming, kapasitas mengikat air, sifat emulsifikasi, serta dapat membentuk film (Chen et al., 2018). IPK memiliki sifat fungsional, warna agak mengkilat, flavor ringan, dan memiliki viskositas rendah sehingga cocok digunakan dalam minuman kaya protein (Winarsi, 2010). Berdasarkan hal tersebut, maka diperlukan penambahan konsentrasi IPK yang tepat sebagai bahan pengisi dalam pembuatan kefir bubuk. Tujuan dari penelitian ini yaitu untuk mengetahui pengaruh IPK terhadap rendemen, total padatan terlarut, $\mathrm{pH}$, derajat kecerahan, kelarutan, kadar air, $a_{w}$, dan total asam kefir bubuk.

\section{BAHAN DAN METODE}

Penelitian ini dilaksanakan pada bulan September - Desember 2019 di Laboratorium Kimia dan Gizi Pangan serta Laboratorium Rekayasa Pangan dan Hasil Pertanian, Fakultas Peternakan dan Pertanian, Universitas Diponegoro, Semarang.

\section{Bahan}

Bahan-bahan pada penelitian ini adalah susu sapi segar, kefir grain, isolat protein kedelai (IPK), larutan PP (phenolptaline) $1 \%$, larutan $\mathrm{NaOH} 0.1 \mathrm{~N}$, dan aquades.

\section{Alat}

Peralatan yang digunakan yaitu cabinet dryer (Maksindo), timbangan analitik, homogenizer (IKA), grinder (Maksindo), pH meter (OHAUS), aw meter (Novasina), refractometer, oven (Memmert), alat titrasi, beaker glass, gelas ukur, kertas saring, toples plastik, panci, kompor, loyang, plastic wrap, sendok, ayakan, dan saringan.

\section{Desain Penelitian}

Pembuatan kefir bubuk ini didesain menggunakan Rancangan Acak Lengkap (RAL) dengan konsentrasi penambahan IPK yang bervariasi yaitu $0 \%, 2.5 \%, 5 \%, 7.5 \%$, dan 10\% dari volume kefir. Data hasil pengujian dianalisis menggunakan Analysis of Variance (ANOVA) dengan taraf kepercayaan 95\%, jika memberikan pengaruh nyata maka dilanjutkan dengan Wilayah Ganda Duncan. Analisis data dilakukan dengan aplikasi SPSS for Windows 25.0. 


\section{Tahapan Penelitian}

\section{Pembuatan Kefir}

Pembuatan kefir dari susu sapi mengacu pada Ginting et al. (2019) yaitu alat yang akan digunakan disterilisasi terlebih dahulu. Kefir grain ditimbang sebanyak $50 \mathrm{~g}$ atau sebanyak $5 \%$ dari volume susu sapi. Susu sapi segar dipasteurisasi terlebih dahulu menggunakan suhu $70^{\circ} \mathrm{C}$ selama 15 detik, selanjutnya diturunkan hingga suhu $30^{\circ} \mathrm{C}$. Susu diukur sebanyak 1 liter kemudian dimasukkan ke dalam toples plastik, lalu ditambahkan kefir grain yang telah ditimbang dan diaduk secara perlahan hingga rata. Kemudian, toples ditutup dan dibungkus menggunakan plastic wrap. Susu diinkubasi pada suhu ruang selama 24 jam. Penyaringan dilakukan agar kefir grain terpisah dari produk kefir.

\section{Pembuatan Kefir Bubuk}

Pembuatan kefir bubuk mengacu pada Al-Baarri et al. (2016) yaitu kefir ditambahkan IPK dengan konsentrasi yaitu $0 \%, 2.5 \%, 5 \%, 7.5 \%$ dan $10 \%$ dari volume kefir. IPK tersebut ditambahkan secara perlahan ke dalam kefir sambil terus diaduk dan dihomogenkan menggunakan homogenizer dengan kecepatan 12000 rpm selama 2 menit. Kefir yang telah tercampur dengan IPK dituangkan ke dalam nampan untuk tempat pengeringan, selanjutnya dikeringkan menggunakan cabinet dryer pada suhu $50^{\circ} \mathrm{C}$ dengan waktu 24 jam. Setelah kefir kering, kefir diangkat dari nampan, lalu dihaluskan menggunakan grinder kemudian diayak menggunakan ayakan 60 mesh agar mendapatkan ukuran yang seragam. Kefir bubuk yang telah didapatkan, kemudian dimasukkan ke dalam ziplock plastic bag yang sudah dilengkapi dengan silica gel food grade untuk menjaga produk agar tetap kering dan mencegah kontaminasi dari luar. Setelah dikemas, kefir bubuk disimpan pada suhu refrigerator.

\section{Metode}

Parameter yang diuji meliputi rendemen (Nusa et al., 2014), total padatan terlarut dengan alat refractometer (Ismawati et al., 2016), nilai pH dengan alat $\mathrm{pH}$ meter (Azizah et al., 2012), derajat kecerahan menggunakan aplikasi colorimeter Color Grab (color detection) pada Android (Nianti et al., 2018), kelarutan dilakukan dengan penyaringan dan pengovenan (AOAC, 1995), kadar air menggunakan metode pengovenan (Sudarmadji et al., 1997), aktivitas air $\left(a_{w}\right)$ dengan alat $a_{w}$ meter (Sarifudin et al., 2015), dan total asam dilakukan metode titrasi $\mathrm{NaOH}$ (Masykur dan Kusnadi, 2015).

\section{Prosedur Analisis}

\section{Uji Rendemen}

Berat awal kefir cair ditimbang, kemudian dilakukan proses pembuatan kefir bubuk dengan ditambahkan bahan pengisi IPK. Berat dari kefir bubuk ditimbang sebagai berat akhir produk. Perhitungan rendemen didapat dengan rumus sebagai berikut:

\section{Uji Total Padatan Terlarut}

$$
\text { Rendemen }=\frac{\text { Berat kefir bubuk }}{\text { Berat kefir cair }} \times 100 \%
$$

Pengujian dilakukan dengan alat refractometer. Prisma refractometer dibilas terlebih dahulu menggunakan aquades dan diseka dengan kain yang lembut. Sampel sebanyak $1 \mathrm{~g}$ dilarutkan dengan $20 \mathrm{ml}$ aquades, selanjutnya disaring menggunakan kertas saring hingga didapat filtrat sampel. Filtrat sampel diteteskan pada prisma refractometer sebanyak 1-2 tetes kemudian hasil dapat dilihat dengan skala pembacaan dalam satuan ${ }^{\circ} \mathrm{Brix}$.

\section{Uji Nilai $\mathrm{pH}$}

Pengujian $\mathrm{pH}$ dilakukan dengan alat $\mathrm{pH}$ meter. Alat $\mathrm{pH}$ meter dinyalakan lalu didiamkan hingga konstan selama 15-30 menit. Sampel kefir bubuk terlebih dahulu direhidrasi menggunakan aquades dengan perbandingan 1:10 (Pangestu et al., 2017). 
Katoda dicelupkan pada sampel lalu dibiarkan beberapa saat hingga hasil pengujian muncul pada display alat dan dicatat.

\section{Uji Derajat Kecerahan}

Pengujian derajat kecerahan menggunakan aplikasi colorimeter Color Grab (color detection) pada Android. Analisis warna yang digunakan adalah nilai L (lightness) yang menyatakan tingkat kecerahan. Nilai kecerahan 0 untuk warna paling gelap atau warna hitam dan 100 untuk warna paling terang atau putih. Masing-masing sampel kefir bubuk yang telah diberi perlakuan diletakkan di bawah kamera dengan tingkat pencahayaan yang sama, kemudian hasil akan muncul sesuai dengan titik yang dipilih. Angka hasil tersebut menunjukkan warna cerah dan gelapnya sampel yang diuji.

\section{Uji Kelarutan}

Pengujian kelarutan kefir bubuk dilakukan dengan $1 \mathrm{~g}$ kefir bubuk ditimbang (a) lalu dilarutkan dengan $20 \mathrm{ml}$ aquades suhu $50^{\circ} \mathrm{C}$ kemudian disaring dengan kertas saring. Sebelum digunakan kertas saring dioven selama 30 menit dengan suhu $105^{\circ} \mathrm{C}$ dan ditimbang (b). Setelah penyaringan, kertas saring dioven dengan suhu $105^{\circ} \mathrm{C}$ sampai tercapai bobot tetap lalu dimasukkan desikator selama 15 menit dan di timbang (c). Perhitungan kelarutan kefir bubuk didapat dengan rumus:

$$
\text { Kelarutan }=1-\left(\frac{(c-b)}{a}\right) \times 100 \%
$$

\section{Uji Kadar Air}

Pengujian dilakukan dengan $2 \mathrm{~g}$ kefir bubuk ditimbang dan dimasukkan ke dalam cawan porselin. Sebelum digunakan, cawan terlebih dahulu dioven selama 60 menit dengan suhu $105^{\circ} \mathrm{C}$. Lalu, kefir bubuk dikeringkan menggunakan oven bersuhu $105^{\circ} \mathrm{C}$ selama 4 jam, selanjutnya dimasukkan pada desikator lalu ditimbang. Kefir bubuk dikeringkan lagi selama 60 menit hingga tercapai berat konstan. Perhitungan kadar air kefir bubuk didapat dengan rumus:

$$
\% \mathrm{KA}=\frac{\text { Berat sampel }-(\text { Berat Setelah Oven }- \text { Berat Cawan })}{\text { Berat Sampel }} 100 \%
$$

\section{Uji Aktivitas Air $\left(a_{w}\right)$}

Pengujian $a_{w}$ menggunakan alat $a_{w}$ meter (Novasina, Jerman) yang telah dikalibrasi. Sampel kefir bubuk dimasukkan dalam chamber sampel, kemudian chamber diletakkan dalam $a_{w}$ meter dan ditunggu pembacaan hasil secara otomatis yang akan muncul pada display alat. Hasil pengujian yang muncul pada display alat dicatat.

\section{Uji Total Asam}

Pengujian ini dilakukan dengan $1 \mathrm{~g}$ kefir bubuk direhidrasi dalam $10 \mathrm{ml}$ aquades, kemudian hasil rehidrasi diletakkan dalam labu ukur $100 \mathrm{ml}$ lalu ditetesi indikator PP $1 \%$. Selanjutnya, kefir rehidrasi dititrasi dengan $\mathrm{NaOH} 0.1 \mathrm{~N}$ sampai terbentuk warna merah muda. Perhitungan total asam didapat dengan:

$$
\text { Total asam }(\%)=\frac{\mathrm{ml} \mathrm{NaOH} \times \mathrm{N} \mathrm{NaOH} \times \mathrm{BE} \text { asam laktat }(90)}{\text { Berat sampel } \times 1000} \times 100 \%
$$


Pengaruh Isolat Protein Kedelai - Rizqiati, dkk

Jurnal Pangan dan Agroindustri Vol.8 No.3: 111-121, Juli 2020

\section{HASIL DAN PEMBAHASAN}

\section{Karakteristik Fisik}

Hasil rerata karakteristik fisik (rendemen, total padatan terlarut, nilai $\mathrm{pH}$, dan derajat kecerahan) kefir bubuk disajikan pada Tabel 1.

Tabel 1. Hasil Uji Karakteristik Fisik Kefir Bubuk

\begin{tabular}{cccccc}
\hline Parameter & $\mathbf{5} \%$ & $\mathbf{2 . 5 \%}$ & $\mathbf{5 \%}$ & $\mathbf{7 . 5 \%}$ & $\mathbf{1 0 \%}$ \\
\cline { 2 - 5 } & $\mathbf{0}$ & $16.03 \pm 0.93^{\mathrm{c}}$ & $18.56 \pm 1.08^{\mathrm{d}}$ & $21.02 \pm 0.84^{\mathrm{e}}$ \\
\hline $\begin{array}{c}\text { Rendemen } \\
(\%)\end{array}$ & $11.40 \pm 0.57^{\mathrm{a}}$ & $13.84 \pm 0.82^{\mathrm{b}}$ & 16.03 & & \\
$\quad \begin{array}{c}\text { Total } \\
\text { Padatan }\end{array}$ & $53.00 \pm 2.00^{\mathrm{c}}$ & $40.00 \pm 0.00^{\mathrm{b}}$ & $39.00 \pm 2.00^{\mathrm{b}}$ & $35.00 \pm 3.83^{\mathrm{a}}$ & $33.00 \pm 2.00^{\mathrm{a}}$ \\
$\begin{array}{c}\text { Terlarut } \\
\text { ('Brix) }\end{array}$ & & & & \\
$\begin{array}{c}\text { Nilai pH } \\
\text { Derajat }\end{array}$ & $4.17 \pm 0.005^{\mathrm{a}}$ & $4.31 \pm 0.018^{\mathrm{b}}$ & $4.40 \pm 0.005^{\mathrm{c}}$ & $4.48 \pm 0.018^{\mathrm{d}}$ & $4.53 \pm 0.017^{\mathrm{e}}$ \\
Kecerahan & $98.72 \pm 0.32^{\mathrm{c}}$ & $97.27 \pm 1.01^{\mathrm{c}}$ & $95.72 \pm 1.65^{\mathrm{bc}}$ & $92.77 \pm 2.22^{\mathrm{ab}}$ & $91.30 \pm 4.13^{\mathrm{a}}$ \\
\hline
\end{tabular}

\section{Rendemen}

Berdasarkan Tabel 1 terlihat bahwa penambahan IPK dengan kosentrasi yang berbeda pada kefir bubuk menunjukkan adanya pengaruh nyata $(p<0.05)$. Rerata rendemen kefir bubuk yang dihasilkan menunjukkan semakin banyak penambahan konsentrasi IPK sebagai bahan pengisi, maka nilai rendemen dari kefir bubuk yang dihasilkan semakin meningkat. Yuliawaty dan Susanto (2015) berpendapat bahwa bahan pengisi dapat meningkatkan massa dan volume bahan sehingga bahan pengisi yang ditambahkan dalam jumlah besar dapat meningkatkan rendemen produk. Peningkatan nilai rendemen juga dipengaruhi oleh sifat IPK yang dapat menyerap air, sehingga air akan terperangkap di dalam komponen dan dapat menambah massa kefir bubuk. Menurut Pahlevi et al. (2008), kemampuan dari bahan pengisi dalam mengikat air dapat meningkatkan rendemen produk. Sumanti et al. (2016) menyatakan bahwa penambahan bahan pengisi dalam jumlah besar dapat meningkatkan viskositas cairan, viskositas yang tinggi menunjukkan semakin banyak lapisan yang mengelilingi bahan inti sehingga rendemen produk tersebut juga semakin meningkat. Semakin tinggi nilai rendemen menunjukkan nilai ekonomis dan efektivitas suatu bahan yang semakin tinggi pula (Putranto et al., 2015). Menurut Risnawati et al. (2017), rendemen merupakan persentase produk sebelum dan sesudah dilakukan pengolahan atau besarnya bahan baku yang dapat dimanfaatkan menjadi produk akhir.

\section{Total Padatan Terlarut}

Dari data pada Tabel 1 terlihat bahwa penambahan IPK dengan konsentrasi berbeda pada kefir bubuk menunjukkan adanya pengaruh nyata $(p<0.05)$ terhadap total padatan terlarut kefir bubuk. Terlihat bahwa semakin tinggi konsentrasi penambahan IPK, menunjukkan total padatan terlarut pada kefir bubuk yang semakin menurun. Penurunan total padatan terlarut pada kefir bubuk ini disebabkan adanya denaturasi protein pada IPK akibat pemanasan dan perubahan $\mathrm{pH}$. Protein akan mengalami denaturasi pada suhu $50^{\circ} \mathrm{C}$ sampai $80^{\circ} \mathrm{C}$ dan menyebabkan protein menjadi sukar larut dalam air (Simanjorang et al., 2012). Darmajana (2012) menambahkan bahwa sebagian besar protein yang terkandung dalam protein kedelai adalah globulin, protein tersebut memiliki titik isoelektris pada $\mathrm{pH} 4.1$ 4.6 sehingga protein akan menggumpal. Total padatan terlarut dapat dipengaruhi oleh adanya denaturasi protein sehingga protein akan mengalami penurunan kelarutan (Suwita et al., 2012). Kelarutan dari IPK yang digunakan tergolong rendah yaitu sebesar $25.55 \%$. Hasrini et al. (2017) menyatakan bahwa IPK memiliki kelarutan yang tidak lebih tinggi jika dibandingkan dengan maltodekstrin, dimana maltodekstrin memiliki kelarutan sekitar $70 \%$. Menurut Ismawati et al. (2016), total gula, asam laktat, dan asam organik yang dihasilkan 
dari aktivitas metabolisme mikroorganisme, pigmen, protein dan vitamin dapat terhitung sebagai total padatan terlarut.

\section{Nilai pH}

Dari Tabel 1 dapat diketahui konsentrasi penambahan IPK yang berbeda pada kefir bubuk memperlihatkan adanya pengaruh nyata $(\mathrm{p}<0.05)$ terhadap nilai $\mathrm{pH}$ kefir bubuk. Terlihat bahwa penambahan IPK sebagai bahan pengisi dengan jumlah besar, maka dapat meningkatkan nilai pH kefir bubuk. Menurut Rukmini dan Naufalin (2015), protein memiliki gugus hidroksil yang dapat mengikat air dan didukung oleh Retnaningsih dan Tari (2014) yang menyatakan bahwa senyawa yang memiliki gugus hidroksil $(-\mathrm{OH})$ dapat menutupi sifat asam yang terdapat dalam bahan. Selain itu, IPK yang digunakan memiliki pH 7.65 sehingga jika ditambahkan dalam jumlah besar dapat mengurangi sifat asam dari kefir. Sejalan dengan Astuti et al. (2014) yang berpendapat bahwa pembuatan isolat protein kedelai dilakukan dengan mengendapkan seluruh protein pada titik isoelektriknya yaitu menggunakan basa encer dengan $\mathrm{pH} 7$ - 9 sehingga apabila IPK ditambahkan dalam jumlah banyak dapat meningkatkan nilai $\mathrm{pH}$. Kualitas kefir yang baik berdasarkan nilai $\mathrm{pH}$ menurut Teijeiro et al., (2018) pada penelitiannya mengenai kefir bubuk menyatakan bahwa minuman kefir memiliki nilai pH khas, yaitu pada kisaran 4 sampai 4.4. Pada penelitian ini, kefir yang dihasilkan memiliki nilai $\mathrm{pH}$ rendah dengan cita rasa yang asam. Nilai $\mathrm{pH}$ yang rendah tersebut karena aktivitas BAL yang menghasilkan asam laktat. Rossi et al. (2016) menyatakan bahwa laktosa diuraikan terlebih dahulu menjadi glukosa dan galaktosa dengan bantuan BAL, kemudian glukosa diubah menjadi asam piruvat pada proses glikolisis dan menghasilkan asam laktat dimana dapat menurunkan $\mathrm{pH}$ dan meningkatkan keasaman.

\section{Derajat Kecerahan}

Berdasarkan Tabel 1 terlihat bahwa konsentrasi penambahan IPK yang berbeda pada kefir bubuk menunjukkan adanya pengaruh nyata $(p<0.05)$ terhadap derajat kecerahan kefir bubuk. Terlihat bahwa penambahan IPK dengan jumlah besar dapat menurunkan tingkat kecerahan kefir bubuk. Penurunan tersebut dikarenakan penambahan bahan pengisi IPK dalam jumlah besar dapat menurunkan mutu sensori terutama warna, karena dapat mengubah warna produk menjadi kecoklatan (Astuti et al., 2014). Poernomo et al. (2011) berpendapat bahwa secara fisik IPK memiliki warna krem atau putih kekuningan. Ario et al. (2015) menambahkan bahwa isolat protein kedelai memiliki warna kekuningan karena mengandung pigmen alami dari kedelai yakni karotenoid dan antoxantin. Sehingga, jika IPK ditambahkan dalam jumlah besar maka dapat menurunkan kecerahan dari kefir bubuk. Suhu pengeringan juga dapat memengaruhi derajat kecerahan karena pembuatan kefir bubuk ini melalui proses pengeringan dengan cabinet dyer suhu $50^{\circ} \mathrm{C}$. Semakin tinggi suhu pengeringan maka akan menurunkan derajat kecerahan, dimana penurunan terjadi karena adanya reaksi pencoklatan non enzimatik pada sampel (Tontul et al., 2018). Wachirasiri et al. (2009) berpendapat bahwa derajat kecerahan dengan nilai $L=100$ memiliki warna terang atau putih sempurna, sedangkan nilai $\mathrm{L}=0$ memiliki warna gelap atau hitam.

\section{Karakteristik Kimia}

Hasil rerata karakteristik kimia (kelarutan, kadar air, aktivitas air $\left(\mathrm{a}_{\mathrm{w}}\right)$, dan total asam) kefir bubuk disajikan pada Tabel 2.

Tabel 2. Hasil Uji Karakteristik Kimia Kefir Bubuk

\begin{tabular}{cccccc}
\hline \multirow{2}{*}{ Parameter } & $\mathbf{5}$ & \multicolumn{3}{c}{ Penambahan IPK } \\
\cline { 2 - 6 } & $\mathbf{0 \%}$ & $\mathbf{2 . 5 \%}$ & $\mathbf{5 \%}$ & $\mathbf{7 . 5 \%}$ & $\mathbf{1 0 \%}$ \\
\hline Kelarutan (\%) & $42.00 \pm 1.82^{\mathrm{c}}$ & $37.42 \pm 5.56^{\mathrm{bc}}$ & $32.25 \pm 5.43^{\mathrm{ab}}$ & $30.68 \pm 2.02^{\mathrm{a}}$ & $26.61 \pm 2.94^{\mathrm{a}}$ \\
Kadar Air (\%) & $14.47 \pm 2.29^{\mathrm{c}}$ & $13.82 \pm 4.35^{\mathrm{bc}}$ & $11.35 \pm 5.76^{\mathrm{abc}}$ & $9.84 \pm 3.01^{\mathrm{ab}}$ & $9.48 \pm 2.86^{\mathrm{a}}$ \\
$\begin{array}{c}\text { Aktivitas Air } \\
(\mathrm{aw})^{\mathrm{ns}}\end{array}$ & $0.52 \pm 0.96$ & $0.52 \pm 0.04$ & $0.45 \pm 0.83$ & $0.44 \pm 0.12$ & $0.43 \pm 0.11$ \\
$\begin{array}{c}\text { Total Asam } \\
(\%)\end{array}$ & $1.21 \pm 0.064^{\mathrm{c}}$ & $1.10 \pm 0.077^{\mathrm{b}}$ & $1.09 \pm 0.056^{\mathrm{b}}$ & $1.05 \pm 0.061^{\mathrm{b}}$ & $0.92 \pm 0.017^{\mathrm{a}}$ \\
\hline
\end{tabular}




\section{Kelarutan}

Dari data pada Tabel 2 dapat diketahui penambahan IPK dengan konsentrasi yang berbeda memperlihatkan adanya pengaruh nyata $(p<0.05)$ terhadap kelarutan kefir bubuk. Penambahan IPK dalam jumlah besar dapat menurunkan kelarutan kefir bubuk. Penurunan ini diduga karena adanya denaturasi protein sehingga menurun kelarutannya. Perubahan kelarutan protein akibat denaturasi disebabkan oleh perubahan struktur protein, dimana lapisan yang bersifat hidrofobik mengalami perubahan lipatan dari arah dalam ke luar sehingga meningkatkan hidrofobisitas (Palupi et al., 2015). Penurunan tersebut terjadi karena banyaknya jumlah protein yang rusak akibat proses pengolahan sehingga menurunkan kelarutan dari kefir bubuk. Menurut Zayas (1997), penurunan kelarutan pada protein terjadi karena adanya denaturasi protein akibat $\mathrm{pH}$, kondisi pengolahan, suhu, jenis pelarut dan kekuatan ionik. Didukung oleh Rhim et al. (2000) bahwa protein kedelai akan membentuk ikatan kompleks yang tidak larut pada pH 2. Rosita et al. (2013) menambahkan bahwa protein di dalam kedelai akan kehilangan sifat kelarutannya pada pH 4.5 sehingga kelarutannya menjadi kecil dan mengendap. Sedangkan, menurut Yuliawaty dan Susanti (2015) semakin tinggi nilai kelarutan maka kualitas produk bubuk semakin baik yang karena mudah disajikan. Jenis dan jumlah bahan pengisi yang ditambahkan memengaruhi kelarutan produk (Hakim dan Chamidah, 2013).

\section{Kadar air}

Dari data pada Tabel 2 terlihat bahwa penambahan IPK dengan konsentrasi yang berbeda menunjukkan pengaruh nyata $(\mathrm{p}<0.05)$. Penambahan IPK dalam jumlah besar dapat menurunkan kadar air kefir bubuk. Penambahan padatan seperti protein dapat menurunkan kadar air suatu bahan (Setyowati dan nisa, 2014). Penurunan kadar air produk diduga karena IPK menyerap air yang terkandung di dalam kefir. Menurut Li et al. (2019), IPK memiliki struktur dengan lapisan terluar yang bersifat hidrofilik sehingga memiliki sifat mengikat air. Selain itu, penurunan kadar air disebabkan oleh menguapnya air dalam produk akibat proses pengeringan (Susanti dan Putri, 2014). Menurut Widiada et al., (2016) kadar air merupakan parameter penentu kualitas dari produk pangan, dimana air memengaruhi daya simpan produk. Semakin tinggi kandungan air produk, maka kualitasnya semakin menurun karena mikroba akan mudah tumbuh pada produk dengan kandungan air tinggi (Solihin et al., 2015).

\section{Aktivitas Air $\left(a_{w}\right)$}

Dari Tabel 2 terlihat bahwa konsentrasi penambahan IPK yang berbeda pada kefir bubuk tidak menunjukkan pengaruh nyata $(p>0.05)$ terhadap $a_{w}$ kefir bubuk. Kefir bubuk pada penelitian ini memiliki $a_{w}$ yaitu berkisar antara $0.43-0.52$. Pada nilai tersebut mikroorganisme seperti bakteri, khamir, dan kapang tidak dapat tumbuh. Menurut Winarno (2007), mikroorganisme memiliki $a_{w}$ optimum untuk pertumbuhannya masing-masing, yaitu kapang dengan $a_{w} 0.60-0.70$, khamir memiliki $a_{w} 0.80-0.90$, dan bakteri dengan $a_{w} 0.90$. Kualitas kefir yang baik berdasarkan nilai $a_{w}$ menurut Teijeiro et al., (2018) pada penelitiannya mengenai kefir bubuk menyatakan bahwa kefir bubuk memiliki nilai $a_{w}$ sekitar $0.2-0.3$. Oleh karena itu, kefir bubuk pada penelitian ini belum memenuhi standar. Hal ini terjadi karena protein dalam IPK yang terdapat dalam kefir bubuk dapat menyerap air. Fatmala dan Adi (2017) yang menyatakan bahwa IPK memiliki gugus hidrofilik yang mampu menyerap air dengan baik. Masithoh dan Fauzi (2014) berpendapat bahwa bahan yang disimpan pada ruangan dengan kelembaban tinggi maka bahan akan menyerap air dari lingkungan dan menyebabkan kadar air meningkat. Semakin kecil kadar air produk, semakin kecil pula nilai $a_{w}$ yang dihasilkan begitu pun sebaliknya (Sari dan Kusnadi, 2015). Menurut Sarifudin et al. (2015), a merupakan air bebas pada produk pangan yang dimanfaatkan mikroorganisme seperti bakteri, kapang, dan khamir untuk tumbuh serta memungkinkan untuk terjadinya reaksi kimia maupun enzimatis. 


\section{Total Asam}

Berdasarkan Tabel 2 dapat diketahui penambahan IPK dengan konsentrasi yang berbeda memperlihatkan adanya pengaruh nyata $(p<0.05)$ pada total asam kefir bubuk. Penurunan total asam terjadi seiring dengan meningkatnya jumlah bahan pengisi yang ditambahkan. Semakin banyak bahan pengisi yang digunakan pada produk susu fermentasi bubuk, maka menghasilkan total asam tertitrasi yang semakin menurun dan total asam menunjukkan hubungan berbanding terbalik dengan $\mathrm{pH}$ sehingga penurunan total asam dapat meningkatkan nilai pH (Djali et al., 2016). Nilai total asam pada kefir bubuk masih memenuhi standar total asam kefir. Kefir mengandung minimal $0.6 \%$ total asam tertitrasi (Codex STAN 243-2003). IPK yang ditambahkan dalam jumlah besar dapat menurunkan total asam kefir bubuk karena penambahan padatan yang berlebih dapat mengganggu BAL saat menghasilkan asam laktat. Penambahan ekstrak kedelai menjadikan ruang gerak bakteri asam laktat terbatas (Sawitri, 2011). Menurut Magalhaes et al. (2011), BAL akan menggunakan laktosa sebagai sumber energi dan merombaknya menjadi asam laktat. Peningkatan jumlah total asam pada produk fermentasi disebabkan oleh banyaknya laktosa yang dapat dirombak oleh BAL (Rosiana et al., 2013).

\section{SIMPULAN}

Penambahan konsentrasi IPK dapat meningkatkan rendemen dan nilai $\mathrm{pH}$, sementara total padatan terlarut, derajat kecerahan, kadar air, kelarutan, dan total asam kefir bubuk mengalami penurunan. Perlakuan penambahan konsentrasi IPK $2.5 \%$ merupakan perlakuan terbaik karena menghasilkan total padatan terlarut, kelarutan, derajat kecerahan tertinggi serta perlakuan tersebut menggunakan IPK dengan kosentrasi IPK paling sehingga lebih ekonomis.

\section{DAFTAR PUSTAKA}

Al-Baarri, A.N., A.M. Legowo, Y.B. Pramono, R.F. Siregar, R.F. Pangestu, H.N. Azhar, R.H. Sarya, dan M.C. Hapsari. Teknik Pembuatan Fruity Powder Yogurt. Indonesian Food Technologist. Semarang

AOAC. 1995. Official Methods of Analysis. AOAC Publisher. Washington DC

Ario, J., E. Julianti, dan E. Yusraini. 2015. Karakteristik egg replacer dari isolat protein kedelai, isolat protein susu, pati jagung, pati kentang, guar gum, dan xanthan gum. J. Rekayasa Pangan dan Pertanian. 3:4, 424-433.

Astuti, R.T., Y.S. Darmono, dan I. Wijayanti. 2014. Pengaruh penambahan isolat protein kedelai terhadap karakteristik bakso dari surimi ikan swangi (Priacanthus tayenus). J. Pengolahan dan Bioteknologi Hasil Perikanan. 3:3, 47-54

Azizah, N., A.N. Al-Baarri, dan S. Mulyani. 2012. Pengaruh lama fermentasi terhadap kadar alkohol, $\mathrm{pH}$, dan produksi gas pada proses fermentasi bioethanol dari whey dengan subtitusi kulit nanas. J. Aplikasi Teknologi Pangan. 1:3, 72-77

Chen, X., D.J. McClements.,Y. Zhu., Y.Chen., L. Zou., W. Liu., C. Cheng, and C.Liu. 2018. Enhancement of the solubility, stability and bioaccessibility of quercetin using proteinbased excipient emulsions. Elsevier. 114, 30-37.

Codex Alimentarius. 2003. Codex Standard for Fermented Milks. CODEX STAN 243-2003

Darmajana, D.A. 2012. Pengaruh suhu dan waktu perendaman terhadap bobot kacang kedelai sebagai bahan baku tahu. Seminar Nasional Penelitian dan Pengabdian pada Masyarakat. Universitas Islam Bandung, Bandung. 159-164

Djali, M., H. Marta dan S. Harnah. 2016. Karakteristik yogurt bubuk kacang koro pedang dengan bahan penyalut maltodekstrin. J. Pascapanen.13:1, 28-35. 
Fatmala, I.A. dan A.C. Adi. 2017. Daya terima dan kandungan protein biskuit substitusi tepung ubi jalar ungu dan isolat protein kedelai untuk pemberian makanan tambahan ibu hamil kek. Media Gizi Indonesia. 12:2, 156-163

Ginting, S.O., V.P. Bintoro, dan H. Rizqiati. 2019. Analisis total BAL, total padatan terlarut, kadar alkohol, dan mutu hedonik pada kefir susu sapi dengan variasi konsentrasi sari buah naga merah (Hylocereus polyrhizus). J. Teknologi Pangan. 3:1, 104-109

Hakim, A.R. dan A. Chamidah. 2013. Aplikasi gum arab dan dekstrin sebagai bahan pengikat protein ekstrak kepala udang. J. Pascapanen dan Bioteknologi Kelautan dan Perikanan. 8:1, 45-54.

Harald, J.B. 2002. Microbiological Application. McGraw-Hill Higher Education. New York

Haryanto, B. 2016. Pengaruh konsentrasi putih telur terhadap sifat fisik, kadar antosianin, dan aktivitas antioksidan bubuk instan ekstrak kulit manggis (Garcinia mangostana L.) dengan metode foam mat drying. J. Kesehatan. 7:1, 1-8

Hasrini, R.F., F.R. Zakaria, D.R. Adawiyah, dan I.H. Suparto. 2017. Mikroenkapsulasi minyak sawit mentah dengan penyalut maltodekstrin dan isolat protein kedelai. $J$. Teknologi dan Industri Pangan. 28:1, 10-19

Imanningsih, N. 2013. Pengaruh suhu ruang penyimpanan terhadap kualitas susu bubuk. J. Agrointek. 7:1, 1-5.

Ismawati, N., Nurwantoro, dan Y.B. Pramono. 2016. Nilai pH, total padatan terlarut, dan sifat sensoris yoghurt dengan penambahan ekstrak bit (Beta vulgaris L.). J. Aplikasi Teknologi Pangan. 5:3, 89-93

Li, D., X. Li, G. Wu, P. Li, H. Zhang, X. Qi, L. Wang and H. Qian. 2019. The characterization and stability of the soy protein isolate/1-Octacosanol nanocomplex. Food Chem. 297, $1-7$.

Magalhaes, K.T., G.V.M. Pereira, C.R. Campos, G.D. Dragone and R.F. Schwan. 2011. Brazilian kefir: structure, microbial communities and chemical composition. Brazilian Journal Microbiol. 42:1, 693-702

Mardiah, N. Novidahlia dan Mashudi. 2012. Determination of drying method (cabinet dryer and fluidized bed dryer) on compound and capasity antioxidant in dried rosela. $J$. Pertanian. 3:2, 104-110

Masithoh, R.E. dan R. Fauzi. 2014. Karakteristik parameter kualitas bubuk tomat selama penyimpanan pada berbagai suhu dan jenis kemasan. J. Teknologi Pertanian. 15:3, $185-190$

Masykur, A. dan J. Kusnadi. 2015. Karakteristik kimia dan mikrobiologi yoghurt bubuk kacang tunggak (Vigna unguiculata L.) metode pengeringan beku (kajian penambahan starter dan desktrin). J. Pangan dan Agroindustri. 3:3, 1171-1179

Nianti, E.E., B. Dwiloka, dan B.E. Setiani. 2018. Pengaruh derajat kecerahan, kekenyalan, vitamin $\mathrm{C}$, dan sifat organoleptik pada permen jelly kulit jeruk lemon (Citrus mdica var Lemon). J. Teknologi Pangan. 2:1, 64-69.

Nusa, I.M., M. Fuadi, dan S. Fatimah. 2014. Studi pengolahan biji buah nangka dalam pembuatan minuman instan. J. Agrium. 19:1, 31-38

Pahlevi, Y.W., T. Estiasih, dan E. Saparanti. 2008. Mikroenkapsulasi ekstrak karoten dari spora kapang oncom merah (Neurospora sp.) dengan bahan penyalut berbasis protein menggunakan metode pengeringan semprot. J. Teknologi Pertanian. 9:1, 31-39

Palupi, N.S., S.R. Sitooris, dan F. Kusnandar. 2015. Perubahan alergenitas protein kacang kedelai dan kacang bogor akibat pengolahan dengan panas. J. Teknologi dan Industri Pangan. 26:2, 222-231

Pangastuti, H. A., D.R. Affandi, dan D. Ishartani. 2013. Karakterisasi sifat fisik dan kimia tepung kacang merah (Phaseolus vulgaris L.) dengan beberapa perlakuan pendahuluan. J. Teknosains Pangan. 2:1, 20-27

Poernomo, D., P. Suptijah, dan N. Nantami. 2011. Karakteristik sosis rasa ayam dari surimi ikan lele dumbo (Clarias gariepinus) dengan penambahan isolat protein kedelai. $\mathrm{J}$. Pengolahan Hasil Perikanan Indonesia. 14:2, 106-114 
Putranto, H.F., A.N. Asikin, dan I. Kusumaningrum. 2015. Karakterisasi tepung tulang ikan belida (Chitala sp.) sebagai sumber kalsium dengan metode hidrolisis protein. $J$. Ziraa'ah. 40:1, 11-20

Retnaningsih, N. dan A.I.N. Tari. 2014. Analisis minuman instan secang: tinjauan proporsi putih telur, maltodekstrin, dan kelayakan usahanya. J. Agrin. 18:2, 129-147

Rhim, J. W., A. Gennadios, A. Handa, C.L. Weller, and M.A. Hanna. 2000. Solubility, Tensile, and Color Properties of Modified Soy Protein Isolate Filmst. Agricultural and Food Chemistry. 48:10, 4937-4941

Risnawati, M. Rais, dan Lahming. 2017. Analisis kelayakan teknis dan ekonomis pada pengeringan biji kenari (Canarium indicum L.) dengan menggunakan alat pengering tipe cabinet dryer. J. Pendidikan Teknologi Pertanian. 3:1, 80-92

Rosiana, E, Nurliana, dan T.T.R. Armansyah. 2013. Lactic acid level and acidity of kefir goat milk fermented by various sugar addition and different time of incubation. J. Medika Veterinaria. 7:2, 87-90

Rosita, D.F., Q. Hardiyanti dan Mustiningsih. 2013. Kajian dampak substitusi kacang tunggak pada kualitas fisik dan kimia tahu. J. Teknologi Pangan. 5:2, 138-149

Rossi, E., F. Hamzah, dan Febriyani. 2016. Perbandingan susu kambing dan susu kedelai dalam pembuatan kefir. J. Peternakan Indonesia. 18:1, 13-20

Rukmini, H.S. dan R. Naufalin. 2015. Formulasi tiwul instan tinggi protein melalui penambahan lembaga serealia dan konsentrat protein kedelai. J. Teknologi Industri Pertanian. 25:3, 190-197

Sari, V.R. dan J. Kusnadi. 2015. Pembuatan petis instan (kajian jenis dan proporsi bahan pengisi). J. Pangan dan Agroindustri. 3:2, 381-389.

Sarifudin, A., R. Ekafitri, D.N. Surahman, dan S.K.D.F.A. Putri. 2015. Pengaruh penambahan telur pada kandungan proksimat, karakteristik aktivitas air bebas $\left(\mathrm{a}_{\mathrm{w}}\right)$ dan tekstural snack bar berbasis pisang (Musa paradisiaca). J. Agritech. 35:1, 1-8

Sawitri, M.E. 2011. Kajian konsentrasi kefir grain dan lama simpan dalam refrigerator terhadap kualitas kimiawi kefir rendah lemak. J. IImu-IImu Peternakan. 21:1, 23-28

Sawitri. M.E. 2011. Kajian penggunaan ekstrak susu kedelai terhadap kualitas kefir susu kambing. J. Ternak Tropika. 12:1, 15-21

Setyowati, W. T. dan F. C. Nisa. 2014. Formulasi biskuit tinggi serat (kajian proporsi bekatul jagung: tepung terigu dan penambahan baking powder. J. Pangan dan Agroindustri. $2: 3,224-231$

Simanjorang, E., N. Kurniawati, dan Z. Hasan. 2012. Pengaruh penggunaan enzim papain dengan konsentrasi yang berbeda terhadap karakteristik kimia kecap tutut. $J$. Perikanan dan Kelautan. 3:4, 209-220

Solihin, Muhtarudin dan R. Sutrisna. 2015. Pengaruh lama penyimpanan terhadap kadar air kualitas fisik dan sebaran jamur wafer limbah sayuran dan umbi-umbian. J. Ilmiah Peternakan Terpadu. 3:2, 48-52

Sudarmadji, S., B. Haryono, dan Suhardi. 1997. Prosedur Analisis Untuk Bahan Makanan Dan Pertanian. Liberty. Yogyakarta

Sumanti, D.M., I. Lanti, I. Hamidah, E. Sukarminah, dan A. Giovanni. 2016. Pengaruh konsentrasi susu skim dan maltodekstrin sebagai penyalut terhadap viabilitas dan karakteristik mikroenkapsulasi suspensi bakteri Lactobacillus plantarum menggunakan metode freeze drying. J. Penelitian Pangan. 1:1, 7-13

Susanti, Y.I. dan W. D. R. Putri. 2014. Pembuatan minuman serbuk markisa merah (Passiflora edulis $f$. edulis Sims) (kajian konsentrasi tween 80 dan suhu pengeringan). J. Pangan dan Agroindustri. 2:3, 170-179

Suseno, R., N.S. Palupi, dan E. Prangdimurti. 2016. Alergenisitas sistem glikasi isolat protein kedelai-fruktooligosakarida. J. Agritech. 36:4, 450-458

Suwita, I.K., Y. Kristianto, dan F.Y. Purwaningsih. 2012. Pendugaan umur simpan sirup temulawak (Curcuma xanthorrhiza Roxb.), madu dan ekstrak ikan gabus (Ophiocephalus striatus) dengan model Arrhenius dan model Q10. J. Agromix. 3:2, 1835 
Teijeiro, M., P.F. Pérez, G.L. De Antoni, and M.A. Golowezyc. 2018. Suitability of kefir powder production using spray drying. Food Research International. 112, 169-174

Tontul, I., F. Ergin, E. Eroğlu, A. Küçükçetin, and A. Topuz. 2018. Physical and microbiological properties of yoghurt powder produced by refractance window drying. International dairy. 85, 169-176

Wachirasiri, P., S. Julakarangka, dan S. Wanlapa. 2009. The effects of banana peel preparations on the properties of banana peel dietary fibre concentrate. $J$. Songklanakarin Sci. Technol. 31:6, 605-611

Widiada, I.G.N., I.K.S. Jaya dan D.Y.E. Sari. 2016. Pengaruh penambahan ikan kembung terhadap sifat organoleptik dan kadar air nugget ampas tahu. J. Gizi Prima. 1:1, 1-5

Winarno, F.G. 2007. Teknobiologi Pangan. M-Brio Press. Bogor

Winarsi, H. 2010. Protein Kedelai \& Kecambah: Manfaatnya bagi Kesehatan. Kanisius, Yogyakarta

Yuliawaty, S.T. dan W.H. Susanto. 2015. Pengaruh lama pengeringan dan konsentrasi maltodekstrin terhadap karakteristik fisik kimia dan organoleptik minuman instan daun mengkudu (Morinda citrifolia L.). J. Pangan dan Agroindustri. 3:1, 41-52

Zayas, J. F. 1997. Functionality of Proteins in Food. Berlin: Springer-Verlag 